\title{
Integration of Solar Energy Resource into Agro-Energy Cooperative Districts: A Case Study based on Solar Powered Irrigation Pumps
}

\author{
A. Rubio-Aliaga ${ }^{1}$, A. Molina-García ${ }^{1}$, J.M.Sánchez-Lozano² and M.S. García-Cascales ${ }^{3}$ \\ ${ }^{1}$ Dept. of Electrical Engineering \\ ${ }^{3}$ Dept. of Electronics, Computer Architecture and Project Engineering \\ Universidad Politécnica de Cartagena, 30202 Cartagena (Spain) \\ Phone/Fax number: +34 986325462 (5354), e-mail: ara10@alu.upct.es, angel.molina@upct.es, socorro.garcia@upct.es \\ ${ }^{2}$ Centro Universitario de la Defensa de San Javier, \\ Academia General del Aire, Universidad Politécnica de Cartagena, Murcia (Spain) \\ Phone/Fax: +34 968189914, e-mail: juanmi.sanchez@cud.upct.es
}

\begin{abstract}
The use of renewable energy resources to decrease both energy dependence and climate change has become a usual solution promoted by most developed countries. Nowadays, a significant number of governments have supported the integration of renewables in a sort of energy sectors, such as industrial customers or rural areas. Under this framework, the present paper describes a case study to integrate solar resource into rural areas for irrigation pumping purposes. This study has been carried out in two Mediterranean countries with similar solar radiation levels but with significantly different energy policies: Spain and Morocco. Results provide an analysis of agro-energy cooperative districts to optimize energy requirements in terms of water pumping and under scarcity conditions, typically found in current Mediterranean areas.

Real data from both rural areas are also included in the paper. The study has been carried out by means of a Geographic Information Systems (GIS) applied to both selected areas.
\end{abstract}

\section{Key words}

Solar Energy Resource, Agro-Energy Cooperative, Water Irrigation Pumps.

\section{Introduction}

According to the International Energy Agency, global energy demand is growing at an average rate of $5 \%$, and it is expected to increase up to a third more until 2035. Under this framework, most developed governments are concerned about the energy dependence issue and the relevant impact of emissions. To mitigate these aspects, current global energy models tend to decrease the presence of fuels in most applications and promote the use and integration of renewable energy resources. Among the different sectors, these objectives can be considered even more complex within the agriculture. In fact, this sector usually involves water scarcity problems and pumping groundwater requirements as well, mainly in the Mediterranean areas where agriculture is crucial for the country economy.
Under this situation of high energy demand and water requirements, irrigated agriculture presents several constraints and significant risks of unsustainable extractions leading to a decrease of chances for the majority of agricultural zones. Traditionally, water pumping requirements in rural areas has been solved by means of diesel generators. However, and attending to current targets in terms of emissions and renewable energy source promotion, this problem must be addressed from an alternative point of view, such as by applying agro-energy cooperative solutions and optimizing natural resources based on solar energy. It is thus necessary to give alternative solutions addressing the potential conversion of current irrigation systems based on fossil fuels towards solar energy solutions, maintaining both reliability and feasibility of the operated systems. In addition, these sustainable developments must consider not only energy and economic constraints, but also minimize water necessities as an attempt to propose more environmental and friendly solutions. Moreover, these alternatives should provide suitable ways to include both environmental and socio-economic benefits. Taking into account this scenario, the present paper describes a case study to integrate solar resource into rural areas for irrigation pumping purposes. This study has been carried out in two Mediterranean countries with similar solar radiation levels but with significantly different energy policies: Spain and Morocco. Results provide an analysis of agro-energy cooperative districts to optimize energy requirements in terms of water pumping under scarcity conditions, typically found in current Mediterra-nean areas. The degree of exploitation for the aquifers are analysed by using a Geographic Information Systems (GIS) applied to both selected areas.

\section{Description of Mediterranean Areas}

Two real equivalent surface areas (100 Ha) have been considered in both countries. To analyse the data of such areas, a Geographic Information System (GIS) has been selected [1] [2]. The areas under study are representative to the traditional Mediterranean agricultural landscape: olives, wheat and grapes. Actually, they are characteristic of vast dry plains which have been put in irrigation over the last century thanks to the progress of technology in agriculture. 


\section{Location of study areas}

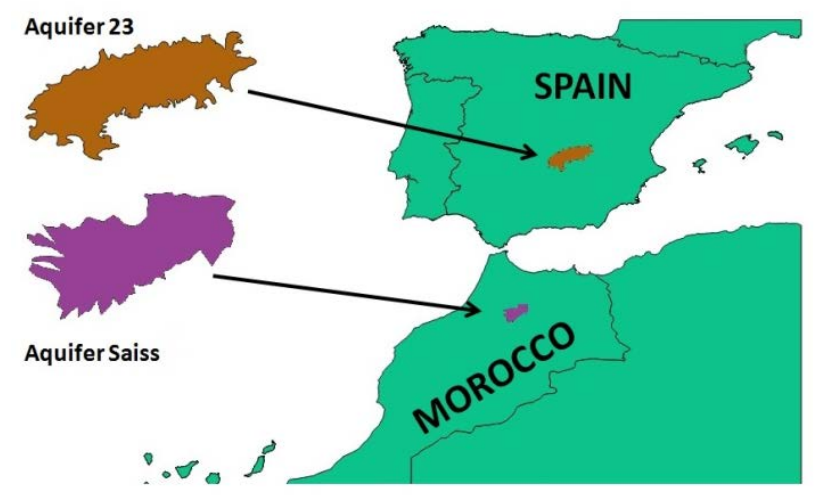

Fig. 1. Location of both regions

Spain. From the geographical point of view, the selected region of La Mancha (South-East of Spain) is a vast plain of $5500 \mathrm{~km}^{2}$ where the aquifer 23 is located in the central area of the upper basin of the Guadiana river, a sedimentary basin of karstic origin. The aquifer beneath this region was declared over-exploited due to unsustainable extractions. Despite some limitations were established and the aquifer was partially recovered, according to [9] it is necessary to regulate and manage water resources in a more efficient way. In fact, agriculture in this region has been promoted by the presence of this aquifer and the Bsk Continental Mediterranean climate, associated with dry and hot summers, and a rainfall between $300-400 \mathrm{~mm}$ focused on spring. The selected area of agriculture is characteristic of this region, and the range of water exploitation is in line with typical wine regions, though influenced by olive and cereal fields as well [10]. The area lies between the cities of Socuéllamos and Tomelloso, with known surface data, cultivation and cadastral maps, as well as solar radiation data and a depth map of the aquifer [11].

Morocco. The area known as the Plain Morocco Meknes-Fes Saiss, around $2200 \mathrm{~km}^{2}$, where these cities are established and important agricultural sector are based on the karstic aquifer Saiss. In a similar way to the area of Spain, this region is also submitted to over-exploitation of water resources, due to high water pressure and water withdrawals for irrigation patterns in a very fertile region. Indeed, agriculture has been significantly improved as a consequence of large investments in modernization and thanks to the Mediterranean climate Csa according to the Köppen-Geiger, with the highest annual average temperature $\left(17.3^{\circ} \mathrm{C}\right)$ and relevant rains during winter, spring and autumn [12]. The selected area is an agricultural surface located in the South-East of Meknes, between the towns of El Fouarate and Bouderbala, with high presence of vineyard, arable land, olive groves and orchards [13].

As both countries has lowered the water table, large financial efforts are necessary due to the energy demand requirements in terms of pumping deep ground-water. This increase in financial resources would affect to the total profit margin of farmers, hurting agriculture in general in these areas and giving an opportunity in energy research to reduce the energy demand of farms, finding more sustainable and efficient solutions based on renewable energy resources [14]. Additionally, reducing $\mathrm{CO}_{2}$ emissions is also a desirable objective, [17], and then, the implementation of renewable energy in agriculture emerges as a suitable way to promote and achieve this emission reduction.

\section{Methodology: General Overview}

The proposed methodology is based on a set of GIS-technical studies, aiming to estimate the most suitable agricultural areas. These areas are determined to implement the solar pumping and find the most appropriate solution in terms of energy efficiency and water requirements, proposing alternative ways for farmers and thus changing their irrigation and energy models. From the two selected areas, solar radiation levels and aquifer depth layer are matched to estimate a solar pumping map, deduced from a relation between solar radiation and the depth of the aquifer. The results can be then considered as an additional layer, providing relevant information about the possibilities of introducing renewable solutions based on photovoltaic installations. Therefore, it is possible to compare both specific areas in different locations and countries. Taking into account the agronomic data of these two areas, related through the layer of applicability, it is possible to obtain data concerning the operation decade farm and the use of water (water needs of the crop water demand and supplied by the pump), as well as energy demand due to water pumping necessities in terms of $\mathrm{CO}_{2}$ emissions.

This study thus allows us to obtain technical data relevant to propose strategic solutions addressing to the problem outlined in the previous section, with the objectives of reducing energy demand, fossil fuel dependence and $\mathrm{CO}_{2}$ emissions. In addition, the integration of agro-energy cooperatives into the agricultural sector is also promoted, as a sustainable solution for current farmer requirements.

The following items summarized the proposed methodology, carried out by means of a Geographic Information Systems (GIS) applied to both selected areas:

1. Radiation maps and depth of the aquifer in both countries are firstly considered. The applicability layer is then obtained as a relation between both layers, see Fig 2 [16].

2. Specific zones are selected according to the applicability layer, see Fig 3.

3. The characteristics of the plots in terms of crop area, water requirements are analysed, see Table I.

4. A sort of different systems and solutions based on PV and diesel with different configurations are proposed.

5. Table I shows the different solutions according to water requirements and energy demand.

6. Table II allows us to compare diesel and solar solutions, as individual and as cooperative systems. $\mathrm{CO}_{2}$ emission levels are included as well.

\section{Proposed Systems: Discussion}

With the aim of estimating the $\mathrm{CO}_{2}$ emissions according to different solutions as well as the optimal size of the energy installations in terms of pumping ground-water necessities, different systems are proposed and discussed:

- Individual changes from diesel to solar pumping solutions This approach consists of changing from diesel energy system to solar pumping solutions by each one of the agricultural plots, in an individually way. In this work, it is taken from the water needs and the energy demand of the pump. PV solar modules of 255W rate power are used with different configurations. 

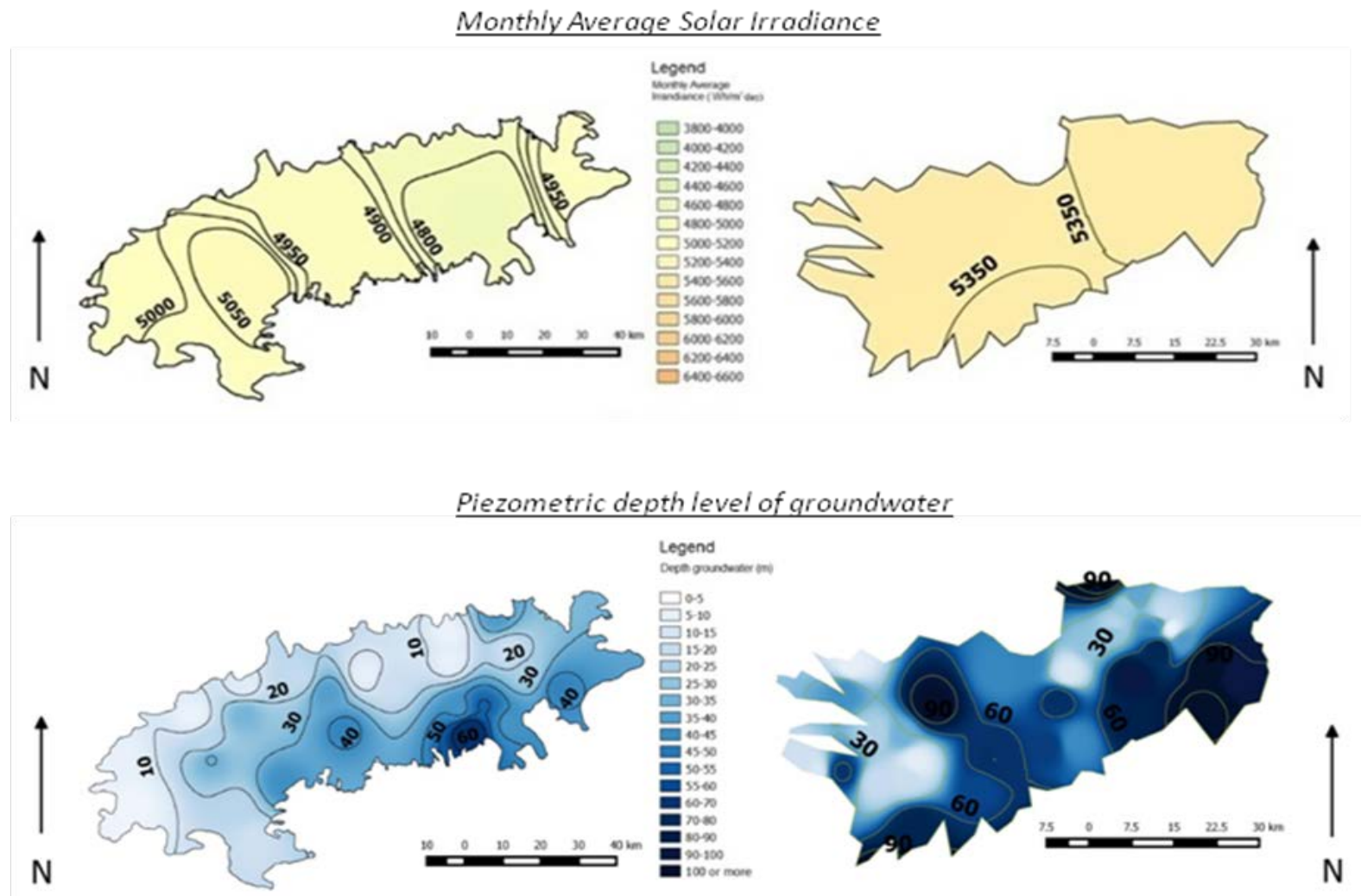

Fig. 2. Layer of Monthly Average Solar Radiation and Piezometric depth level of groundwater.
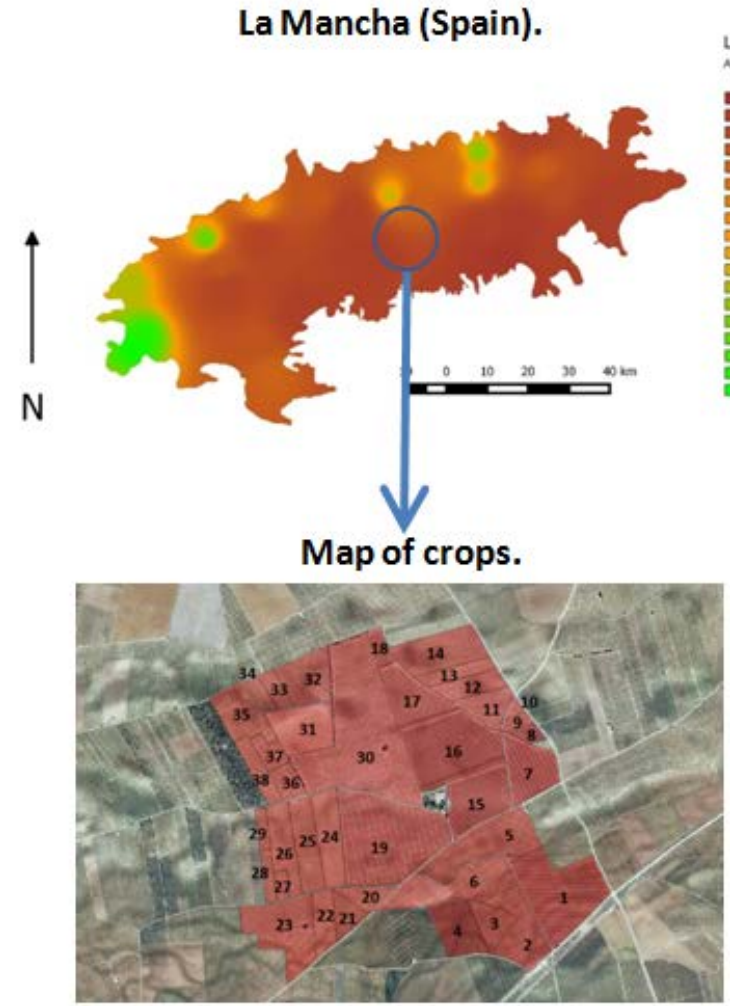

Saiss(Meknes-Fes, Maroc).
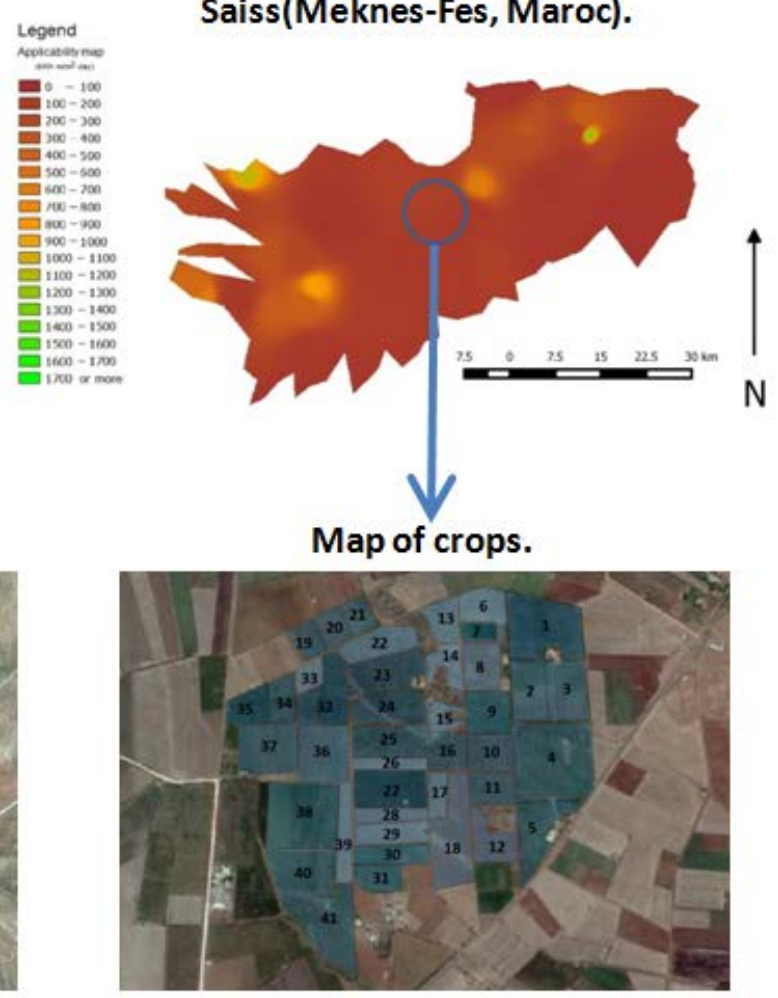

Fig. 3. Applicability layer with maps of agricultural areas in both countries. 


\section{- Proposed system 1. Diesel equipment in cooperative}

A solution including a diesel group (2 groups of $64 \mathrm{kVA}$ in Spain and 4 groups of 64kVA in Morocco) is firstly considered. These diesel groups are able to provide the power demanded by the water pumping necessities, aiming to cover the irrigation of the set of the plots. The irrigation patterns are based on the farmer's schedules. Systems 2 and 3 are also proposed, considering farmer's irrigation patterns in one sector of their agricultural plot.

\section{- Proposed system 2. Installation of PV solar pumping in cooperative}

The following system consists of a PV solar system in charge of providing the same power as the previous system. Therefore, the PV solar installation must be operated to cover pumping requirements and to remove other power demand necessities for crops. For the proposed cooperative systems, it has been considered by these studies the global pumping energy demand also considering pressure losses due to the extended irrigation network.

\section{- Proposed system 3. Installation of PV solar pumping with reservoir in cooperative}

The third system consists of an installation with reservoir enable to run along the whole year, with pumping requirements during the different seasons and months, pointing out those months in which it is necessary to irrigate the crops. Obviously, this system requires a smaller PV system, but it requires a reservoir to store water throughout the year.

For the Spanish case, around 25\% of energy requirements are needed to pressurize the water and $75 \%$ to pump ground-water. In the case of Morocco, $80 \%$ of the total energy is required to obtain water from the aquifer. Consequently, if it is distributed in a proportional and similar way throughout the year, the water required for pumping, while the raft is filled, it is possible to reduce the number of modules. In this study, the evapotranspiration losses produced in the storage tank has been neglected.

\section{Results}

Firstly, the results are focused on the application layer, which depicts the rate of applicability associated with the relations between solar radiation levels and the depth of the aquifers for each study areas. These preliminary results give an initial analysis to estimate the optimal integration of solar energy into agriculture, as well as the area chosen in Spain with a level of applicability of $245 \mathrm{Wh} \cdot \mathrm{m}$ and the area of Morocco with a value of $133 \mathrm{Wh} \cdot \mathrm{m}$.

Table I compares the corresponding plots of both agricultural regions (Spain and Morocco). Different solutions are summarized in Table II for pumping irrigation water. This comparison is carried out from different points of view: energy, and environmental such as $\mathrm{CO}_{2}$ emissions, including emissions savings as a consequence of the changes from diesel to PV solar systems. Furthermore, this analysis briefly assesses the costs and draw a SWOT (strengths, weaknesses, opportunities and threats) for each one of the proposed systems.

From a global reduction of $\mathrm{CO}_{2}$ emissions, a remarkable decreasing is achieved, though the addition of individual efforts is greater than the economic case 3 . This system could give better benefits connected to a smart grid, which would work as the installation case 2 . Therefore, an additional benefit can be provided to the farmers, allowing them to sell the energy generated in winter periods.
An important drawback is the high dispersion of installations, which could lead to unsafety systems due to the lack of security in the field. In the first case, it is shown that the individual cost of diesel installation equipment is reduced as well as the energy required due to the efficiency of the equipment itself. Emissions practically are remained almost constant or slightly diminished, but certainly it is not the most optimal solution, as they are still dependent on fossil fuels.

Regarding the second case, the system can be oversized since it is a large installation with a use reduced to 3 months. Nevertheless, it has the advantage of allowing the sale of energy during the rest of the year when it is not necessary to irrigate the crops, generating an additional benefits to the farmers' cooperative. The system has an important drawback, since the hydraulic calculations do not consider the local lowering of the well relating to the big quantities of water to be extracted.

For the third case, it has the advantage that the installation is smaller than the previous solutions and then the installation costs are reduced. However, it is necessary to add the cost of the raft of deposit $\left(190000 \mathrm{~m}^{3}\right.$ Spain, Morocco $\left.223000 \mathrm{~m}^{3}\right)$. The well couldn't suffer local lowering, but it couldn't sell high amounts of energy. Subsequently, PV solar installation is oriented almost exclusively for an annual agricultural use. Among others, it creates other economic benefits, such as jobs in operations, maintenance and security.

The final results show that, for a set of agricultural plots of both zones, the energy demand per hectare $(\mathrm{Ha})$ is the same for individual diesel equipment that for installations of PV solar power applied to water pumping requirements. Indeed, since the energy demand represents the necessities to raise the water from the subsoil, this amount of energy is practically the same for clusters or individual systems. However, the selection of individual diesel equipment or PV solar pumping (with different $\mathrm{PV}$ module technologies) decline the $\mathrm{CO}_{2}$ emissions.

On the other hand, in cooperative terms, [18-19], the clustering of agricultural plots under an agro-energetic cooperative in the irrigation with a raft with a diesel equipment would reduce very slightly emissions of $\mathrm{CO}_{2}$, and costs. Nevertheless, an agroenergetic cooperative with an installation of PV solar pumping with an raft, needs a lower size of the global installation and reduces the emission of $\mathrm{CO}_{2}$ significantly, providing additional economic and social benefits.

\section{Conclusions}

A case study to integrate solar resource into rural areas for irrigation pumping purposes is described and assessed. This study has been carried out in two Mediterranean countries with similar solar radiation levels but with significantly different energy policies: Spain and Morocco. According to the results, it is possible to achieve a suitable management of energy resources and water requirements, leading to remove downtime and promote savings based on PV solar investment.

The study case provides relevant information on two areas, by considering regions with different levels of applicability, solar radiation and groundwater, as well as different models of Mediterranean agriculture: mono-cropping vs. orchards, cereal, vine... with different water consumption patterns depending on the crop, which provides useful information about the variation of water and energy needs, $\mathrm{CO}_{2}$ emissions and design of a installation in proposed cooperative energy systems. 
According to the results, the implementation of renewables in agriculture offers a more sustainable use of energy in comparison with diesel equipment, reducing significantly the emissions. The implementation in cooperatives of renewable installations allow a more efficient use of energy and, for PV solar pumping systems, they are able to reduce the cost of the PV system improving other factors, such as security and the irrigation automation process.

In future work, several influences of agricultural benefits and the suitability of the proposed systems in relation with personal farmer economy will be studied in detail. Another future work it is focused on estimating economic variations for PV solar pumping installations including reservoir, aiming to optimize economic resources based on different variables, such as energy demand, water requirements, crops and the depth of the aquifer.

\section{Acknowledgements}

This work has been partially supported by funds, DGICYT and Junta de Andalucía under projects TIN 2014-55024-P and P11-TIC-8001, respectively.

\section{References}

[1] R. Li, X. Liu, Y. Sun, "Integrated assessment model for solar energy resource based on GIS", in the International Conference on Multimedia Technology (2010), pp. 1-4.

[2] J. Domínguez, J. Amador, "Geographical information systems applied in the field of renewable energy sources", Computers Industrial Engineering 52(3), 2007, pp. 322-326.

[3] Renewable Energies Plan (PANER) 2011-2020, Tech. rep., Institute for Energy Diversification and Saving IDAE (2010).

[4] M. D. Gómez-López, M. S. García-Cascales, E. RuizDelgado, "Situations and problems of renewable energy in the region of Murcia, Spain", Renewable and Sustainable Energy Reviews 14(4), 2010, pp- 1253-1262.

[5] T. Weiss, D. Schulz, "Development of fluctuating renewable energy sources and its influence on the future energy storage needs of selected European countries", in the $4^{\text {th }}$ International Youth Conference on Energy (2013), pp. 1-5.

[6] M. Islam, I. Kubo, M. Ohadi, A. Alili, "Measurement of solar energy radiation in Abu Dhabi, Applied Energy 86(4), 2009, pp. 511-515.

[7] A. Neshat, B. Pradhan, M. Dadras, "Groundwater vulnerability assessment using an improved DRASTIC method in GIS”, Resources, Conservation and Recycling, 86, 2014, pp. 74- 86 .

[8] M. G. Salim, Selection of groundwater sites in Egypt, using geographicinformation systems, for desalination by solar energy in order to reducegreenhouse gases, Journal of Advanced Research 3 (1) (2012) 11-19.

[9] M. Mejías Moreno, Contribución al conocimiento hidrogeológico de la Unidad Hidrogeológica 04.04 (Mancha Occidental). Análisis de la evolución piezométrica, Tech. rep., Dirección de Hidrogeología y Aguas Subterráneas. IGME.

[10] A. Ruiz Pulpón. Tipología territorial de la agricultura de regadío de los municipios de la cuenca hidrográfica del Guadiana. Consejo Económico y Social de Castilla La Mancha, 2007.

[11] Confederación Hidrográfica del Guadiana. Anuncio de la Confederación Hidrográfica del Guadiana sobre Régimen de Explotación para el año 2013 del Acuífero de laMancha Occidental.Boletín Oficial de la Provincia de Cuenca, Pág 4 Num 1402012.
[12] F. Amraoui, Contribution a la connaissance des aquifíeres karstiques: cas du Lias de la plaine du Sais et du Causse Moyen Atlasique tabulaire (Maroc)

[13] Etude de la Faisabilite de Transfert du HautSebouvers la Plaine du Saiss,Tech. rep., Agence du Bassin Hydraulique du Sebou, rapport de synthese (Novembre 2006).

[14] A. Iglesias, L. Garrote, F. Flores, M. Moneo, Challenges to manage the riskof water scarcity and climate change in the mediterranean,Water ResourcesManagement 21 (5) (2007)

[15] F. R. C. Bengoetxea, Energía Renovable y Desarrollo Sostenible, DYNA, Energía 81 (4) (Mayo 2006) 41-44.

[16] A. R. Aliaga, M. S. García-Cascales, A. M. García, J. M. Sánchez-Lozano, Sistemas de información geográfica para optimización e integración de energía solar fotovoltaica en zonas agrícolas con dificultades energéticas e Hídricas, XIX Congreso Internacional de Dirección e Ingeniería de Proyectos Granada.

[17] K. Kato, A. Murata, K. Sakuta, Energy pay-back time and life-cycle $\mathrm{CO}_{2}$ emission of residential pv power system with silicon pv module, Progress in Photovoltaics: Research and Applications 6 (2) (1998)

[18] D. Toke. Community wind power in Europe and in the UK.Wind Engineering Volume 29, $\mathrm{n}^{\circ}$. 3, pp 301-308, 2005.

[19] J. Frayssignes. The concept of "agro-energy district": a pertinent tool for the sustainable development of rural areas. 51st Congress of the European Regional Science Association, Barcelona, 2011. 
Table I. -Comparison of solutions with Solar Energy Source integration for each agricultural plots.

\begin{tabular}{|c|c|c|c|c|c|c|}
\hline \multicolumn{3}{|c|}{ La Mancha (Spain) } & Comparison Installation & \multicolumn{3}{|c|}{ Saiss (Morocco) } \\
\hline \multicolumn{3}{|c|}{ Vineyard } & Culture & \multicolumn{3}{|c|}{ Vineyard } \\
\hline \multicolumn{3}{|c|}{1} & Surface (ha) & \multicolumn{3}{|c|}{1} \\
\hline June & July & August & Irrigation Analysis & June & July & August \\
\hline 25,4362 & 31,6354 & 27,2034 & Total water to apply ( $\mathrm{m}^{3} / \mathrm{ha} \cdot$ dav $)$. & 26,3986 & 32,3082 & 30,3624 \\
\hline \multicolumn{3}{|c|}{1535,85} & Total water $\left(\mathrm{m}^{3 /} \mathrm{ha}\right)$ & \multicolumn{3}{|c|}{2701,95} \\
\hline \multicolumn{7}{|c|}{ Pump Desing } \\
\hline \multicolumn{3}{|c|}{$\frac{21,82}{3120,99}$} & Depth groundwater (m.c.a.) & \multicolumn{3}{|c|}{50,76} \\
\hline \multirow{2}{*}{\multicolumn{3}{|c|}{3120,99}} & Power demanded by the pump (W) & \multicolumn{3}{|c|}{5333,63} \\
\hline & & & \multicolumn{4}{|l|}{ OPTION 1: Diesel generator equipment } \\
\hline \multicolumn{3}{|c|}{3744,24} & Power required $(\mathrm{W})$ & \multicolumn{3}{|c|}{6656,37} \\
\hline \multicolumn{3}{|c|}{ 4KVA } & Power of diesel generator standart (W) & \multicolumn{3}{|c|}{ 8KVA } \\
\hline \multicolumn{3}{|c|}{0,2658} & Emissions $\mathrm{kgCO}_{2} / \mathrm{kWh}$ & \multicolumn{3}{|c|}{0,2658} \\
\hline \multicolumn{3}{|c|}{720,00} & Total Energy generated kWh in summer & \multicolumn{3}{|c|}{1520,00} \\
\hline \multicolumn{3}{|c|}{191,38} & Total Emissions $\left(\mathrm{kgCO}_{2}\right)$ & \multicolumn{3}{|c|}{404,02} \\
\hline \multicolumn{7}{|c|}{ OPTION 2: PV-Pump } \\
\hline \multicolumn{3}{|c|}{6,813} & HPS & \multicolumn{3}{|c|}{6,903} \\
\hline \multicolumn{3}{|c|}{8} & Max Hours Operating & \multicolumn{3}{|c|}{8} \\
\hline \multirow{2}{*}{\multicolumn{3}{|c|}{$\frac{255}{20}$}} & Wp modules & \multirow{2}{*}{\multicolumn{3}{|c|}{$\frac{255}{32}$}} \\
\hline & 20 & & Real No Modules & & 32 & \\
\hline \multicolumn{3}{|c|}{5100} & Installed Power & \multicolumn{3}{|c|}{8160} \\
\hline & 918 & & Total Energy generated $\mathrm{kWh}$ in summer & & 1550,40 & \\
\hline CdTe & Mono-Si & Poly-Si & Technologies & CdTe & Mono-Si & Poly-Si \\
\hline 12 & 45 & 37 & Emissions $\mathrm{gCO}_{2} / \mathrm{kWh}$ & 12 & 45 & 37 \\
\hline 11,02 & 41,31 & 33,97 & Total Emissions $\mathrm{kgCO}_{2}$ & 18,60 & 69,77 & 57,36 \\
\hline 180,36 & 150,07 & 157,41 & $\mathrm{kgCO}_{2}$ emissions avoided & 385,41 & 334,25 & 346,65 \\
\hline
\end{tabular}

Table II a. - Comparison of solutions with Solar Energy Source integration and Diesel Equipment. SPAIN

\begin{tabular}{|c|c|c|c|c|c|c|c|c|c|c|c|c|}
\hline \multirow[t]{2}{*}{ no } & \multirow[t]{2}{*}{$\begin{array}{l}\text { area } \\
\text { (ha) }\end{array}$} & \multirow[t]{2}{*}{ crop } & \multirow[t]{2}{*}{$\begin{array}{c}\text { Water needs } \\
\left(\mathrm{m}^{3}\right)\end{array}$} & \multicolumn{3}{|c|}{ Diesel Generator } & \multicolumn{3}{|c|}{ Direct Solar Pumping } & \multicolumn{3}{|c|}{ Solar Pumping with reservoir } \\
\hline & & & & $\begin{array}{l}\text { Diesel } \\
\text { Power } \\
\text { Installed } \\
\text { kVA }\end{array}$ & \begin{tabular}{|l|} 
Total Diesel \\
Consumptio \\
$\mathrm{n}(\mathrm{I})$
\end{tabular} & \begin{tabular}{|l|} 
Energy \\
Generated \\
$(\mathbf{k W h})$
\end{tabular} & \begin{tabular}{|l|} 
Solar \\
Photovoltaic \\
Power \\
Installed kW
\end{tabular} & Modules & \begin{tabular}{|l|} 
Energy \\
Generated \\
(kWh)
\end{tabular} & \begin{tabular}{|l|} 
Solar \\
Photovoltai \\
c Power \\
Installed \\
kW
\end{tabular} & Modules & \begin{tabular}{|l} 
Energy \\
Generated \\
(kWh)
\end{tabular} \\
\hline Total & 123,5 & & 190082 & 593 & 29170,8 & 106740 & 679,07 & 2663 & 103896,95 & & & \\
\hline $\begin{array}{l}\text { proposed } \\
\text { system } 1\end{array}$ & 123,5 & & 190082 & $128(2 \times 64)$ & 24300 & 103680 & & & & & & \\
\hline $\begin{array}{l}\text { proposed } \\
\text { system } 2 \\
\end{array}$ & 123,5 & & 190082 & & & & 148,92 & 584 & 103290,91 & & & \\
\hline $\begin{array}{l}\text { proposed } \\
\text { system } 3\end{array}$ & 123,5 & & 190082 & & & & & & & 58,65 & 230 & 104895,52 \\
\hline
\end{tabular}

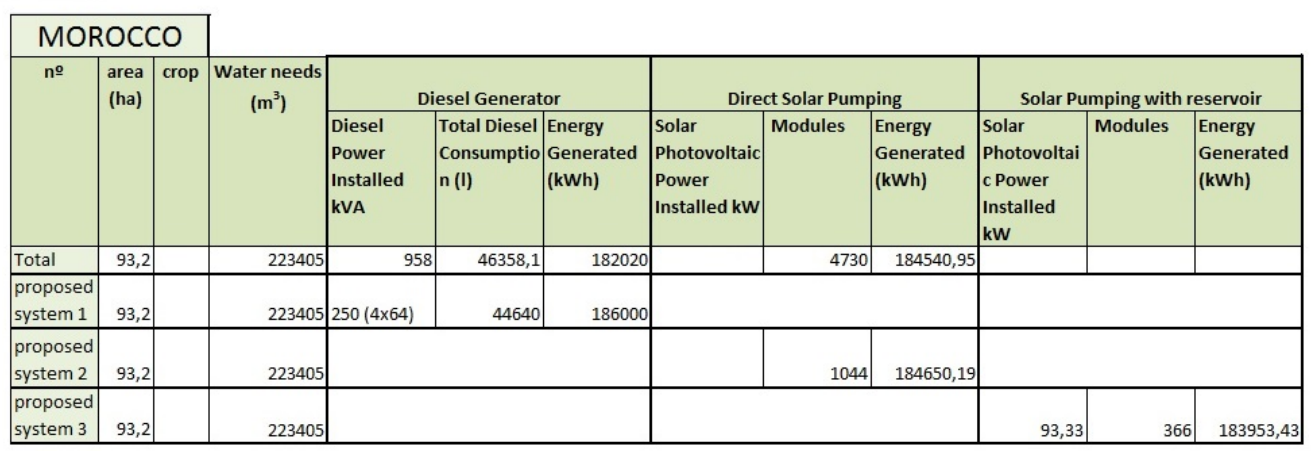

Table II b. - Comparison of emissions of $\mathrm{CO}_{2}$ of different proposed systems.

\begin{tabular}{|c|c|c|c|c|c|c|c|c|c|}
\hline \multirow{3}{*}{$\begin{array}{r}\text { SPAIN } \\
\text { no }\end{array}$} & & & & & \multicolumn{5}{|l|}{ MOROCCO } \\
\hline & \multirow{2}{*}{\begin{tabular}{|l|}
$\mathrm{CO}_{2}$ \\
Emissions \\
Diesel \\
$\left(\mathrm{kgCO}_{2}\right)$
\end{tabular}} & \multicolumn{3}{|c|}{ Photovoltaic Emissions } & no & \begin{tabular}{|l|}
$\mathrm{CO}_{2}$ \\
Emissions
\end{tabular} & \multicolumn{3}{|c|}{ Photovoltaic Emissions } \\
\hline & & \begin{tabular}{|l|}
$\mathrm{Cd}-\mathrm{Te}$ \\
$\left(\mathrm{kgCO}_{2}\right)$
\end{tabular} & \begin{tabular}{|l|}
$\mathrm{m}-\mathrm{Si}$ \\
$(\mathrm{kgCO}$
\end{tabular} & p-Si $\left(\mathrm{kgCO}_{2}\right)$ & & $\begin{array}{l}\text { Diesel } \\
\left(\mathrm{kgCO}_{2}\right)\end{array}$ & \begin{tabular}{|l|}
$\mathrm{Cd}-\mathrm{Te}$ \\
$\left(\mathrm{kgCO}_{2}\right)$
\end{tabular} & \begin{tabular}{|l|}
$\mathrm{m}-\mathrm{Si}$ \\
$\left(\mathrm{kgCO}_{2}\right)$
\end{tabular} & p-Si $\left(\mathbf{k g C O}_{2}\right)$ \\
\hline Total & 28371,49 & 1246,76 & 4675,36 & 3844,19 & 39 & 1212,05 & 56,18 & 210,68 & 173,23 \\
\hline \begin{tabular}{|l} 
proposed \\
system 1
\end{tabular} & 27558,14 & & & & 40 & 1212,05 & 56,18 & 210,68 & 173,23 \\
\hline $\begin{array}{l}\text { proposed } \\
\text { system } 2\end{array}$ & & 1239,49 & 4648,09 & 3821,76 & 41 & 909,04 & 42,14 & 158,01 & 129,92 \\
\hline $\begin{array}{l}\text { proposed } \\
\text { system } 3\end{array}$ & & 1258,75 & 4720,30 & 3881,13 & Total & 48380,92 & 2214,49 & 8304,34 & 6828,02 \\
\hline & & & & & proposed system 1 & 49438,80 & & & \\
\hline & & & & & proposed system 2 & & 2215,80 & 8309,26 & 6832,06 \\
\hline & & & & & proposed system 3 & & 2207,44 & 8277,90 & 6806,28 \\
\hline
\end{tabular}

